\title{
Persepsi Mahasiswa terhadap Pembelajaran Online pada masa Pandemi COVID-19
}

\author{
Mahmud Yunus \\ Universitas PGRI Semarang \\ mahmud_yunus@gmail.com \\ David Firna Setiawan \\ Universitas PGRI Semarang \\ davidfirnasetiawan@gmail.com \\ Endang Wuryandini \\ Universitas PGRI Semarang \\ dyne64@yahoo.com
}

\begin{abstract}
Abstrak
Salah satu upaya untuk mencegah penyebaran Covid-19 adalah belajar dari rumah. Pembelajaran online merupakan alternatif untuk meerapkan pembelajaran dari rumah. Penelitian ini bertujuan untuk menganalisis persepsi mahasiswa terhadap penerapan pembelajaran online, penggunaan aplikasi yang sesuai dalam pembelajaran online dan kelebihan serta hambatan dalam penerapan pembelajaran online pada masa pandemic Covid-19. Penelitian ini menggunakan penelitian kualitatif. Jenis data yang digunakan adalah data primer dan data sekunder. Teknik pengambilan data dengan dokumentasi dan wawancara. Informaan dalam penelitian ini adalah mahasiswa sejumlah 128 mahasiswa. Teknik analisis data menggunakan analisis data interaktif Miles dan Huberman. Hasil Penelitian sampak dari Pandemic Covid-19 salah satunya adalah meniadakan perkuliahan secara langsung. Perkuliahan dilaksanakan dengan menggunakan pembelajaran online aplikasi yang sering digunakan dalam perkuliahan online adalah Google Clasroom, Zoom, Whatshap, Slack, Schoology, Google Clasroom, Zoom, Whatshap, Slack, Schoology, Youtube, Quizizz, Edmodo dan menggunakan aplikasi SIP (Sistem Informasi Perkuliahan) Universitas PGRI Semarang. Kelebihan pembelajaran online dimasa pandemic covid- 19 adalah mempermudah mahasiswa dan dosen tetap melaksanakan perkuliahan meskipun tidak bertemu secara langsung. hambatan pelaksanaan pembelajaran online diantaranya adalah sinyal jaringan internet yang kurang stabil, hal ini dikarenakan sebagian mahasiswa sedang berada dirumah yang tergolong masih pedesaan dengan fasilitas jaringan internet yang belum maksimal. Kesimpulan penelitian menunjukan bahwa persepsi mahasiswa terhadap pembelajaran online sebesar $46,9 \%$ menjawab membantu memahami materi perkuliahan. Sebesar $39,1 \%$ menjawab pembelajaran online dapat meningkatkan motivasi belajar, hanya sebesar $21,6 \%$ mahasiswa menjawab pembelajaran online berjalan efektif. aplikasi yang dianggap efektif dalam pembelajaran online adalah google classroom, whatsap dan SIP. Pembelajaran online memiliki kelebihan dan hambatan dalam pelaksanaanya Kata Kunci Persepsi, Mahasiswa, Pembelajaran Online, Covid-19
\end{abstract}

\section{PENDAHULUAN}

Saat ini dunia sedang menghadapi pandemi Coronavirus Disease (Covid-19) (Jati, 2020). Surveillances (2020) menjelaskan Covid-19 pertama kali dilaporkan di Wuhan, China pada bulan Januari 2020, lalu dengan cepat menyebar ke seluruh provinsi di China $(K u$, 2020). Pada tanggal 21 Mei 2021 virus ini telah menyebar ke 213 negara. Sebanyak 165,857,655 orang 
dinyatakan positif dan 3,444,901 orang meninggal dunia (WHO, 2020). Indonesia merupakan salah satu negara yang terdampak Covid-19. Data menunjukan orang yang positif virus corona di Indonesia berjumlah 1,758,898 dan 48,887 diantaranya meninggal dunia (Worldometers, 2021).

Berbagai negara telah melakukan kebijakan karantina wilayah (Piguillem, 2020), bahkan beberapa negra membuat kebijakan lockdown untuk menahan penyebaran virus (Alfano, 2020). Penerapan lockdown dimulai di Kota Wuhan China (Lau, 2020) dilanjutkan Italy (Alvarez, 2020), Spanyol (Mitjà, 2020), Perancis (Busch, 2020) dan diikuti oleh beberapa negara. Indonesia tidak menerapkan kebijakan lockdown (Mungkasa, 2020), akan tetapi Pemerintah telah melakukan berbagai upaya untuk mencegah penyebaran Covid-19 (Telaumbanua, 2020). Upaya pencegahan Covid-19 yang dilakukan oleh Pemerintah Indonesia salah satunya adalah himbauan untuk melakukan Social Distancing (Hilmatussa'diah, 2020).

Social Distancing atau menjaga jarak sosial dengan langkah belajar dari rumah, bekerja dari rumah dan beribadah dirumah (Darmalaksana, 2020). Penerapan kebijakan Social Distancing tidak hanya berdampak pada dunia ekonomi saja (Abidah A. H., 2020) tetapi juga berdampak pada dunia pendidikan (Purwanto, 2020). Kementerian Pendidikan dan Kebudayaan (Kemendikbud, 2020) membuat kebijakan dengan menerbitkan Surat Edaran Nomor 4 Tahun 2020 tentang pelaksanaan kebijakan pendidikan dalam masa darurat penyebaran Coronavirus Disease (Covid-19), yang isinya antara lain membuat kebijakan untuk proses belajar mengajar dilakukan dari rumah, melalui pembelajaran daring atau pembelajaran online secara jarak jauh.

Pembelajaran online dianggap sebagai alternatif yang logis pada masa pandemic Covid19 (Praherdhiono, 2020). Menurut (Herayanti, 2017) pembelajaran online merupakan jenis pembelajaran yang memungkinkan materi belajar sampai ke peserta didik dengan menggunakan media internet. (Kuntarto, 2017) menjelaskan melalui pembelajaran online mahasiswa dapat belajar dimana saja, meskipun jarang dengan dosen tidak dalam satu ruangan tetapi proses perkuliahan dapat berjalanan. (Djaja, 2017) berpendapat pembelajaran online memerlukan penguasaan teknologi dan kompetensi, terutama bagi pendidik dalam menyajikan pembelajaran online. Aplikasi yang digunakan dalam pembelajaran online antara lain dengan menggunakan aplikasi Google Classroom (Al-Maroof, 2018), menggunakan aplikasi Whatshap (Prajana, 2017), menggunakan aplikasi Zoom Cloud Meeting (Seran, dkk, 2020) dan aplikasi lain yang dapat mendukung terlaksananya pembelajaran online.

Berdasarkan kebijakan Pemerintah dan surat edaran dari Kemendikbud, setiap sekolah dan universitas dituntut untuk dapat menyelenggarakan pembelajaran online dari rumah masingmasing (Sanjaya, 2020). Penerapan pembelajaran online juga dilaksanakan oleh Pendidikan Ekonomi Universitas PGRI Semarang. Penerapan kegiatan belajar dari rumah melalui pembelajaran online perlu dianalisis dari sudut pandang mahasiswa, untuk mengetahui respon mahasiswa mengenai kelebihan dan hambatan dalam penerapan pembelajaran online .

Tujuan penelitian ini adalah ingin mengetahui persepsi mahasiswa terhadap penerapan pembelajaran online, aplikasi apa saja yang sesuai digunakan dalam pembelajaran online dan hambatan penerapan pembelajaran online pada masa pandemic Covid-19.

\section{LANDASAN TEORI}

\section{Pembelajaran Online}

Pembelajaran online menurut (Belawati, 2019) meupakan pembelajaran yang dilakukan melalui jaringan internet. dalam Bahasa Indonesia pembelajaran online diterjemahkan sebagai pembelajaran dalam jaringan' atau 'pembelajaran daring. pembelajaran online menurut (Henderson, 2003) yaitu memungkinkan peserta didik belajar tanpa harus pergi ke ruang kelas, dan pembelajaran dapat dijadwalkan sesuai kesepakatan antara instruktur dan peserta didik, atau peserta didik dapat menentukan sendiri waktu belajar yang diinginkan.

Sistem pembelajaran online membutuhkan teknologi pendukung yang mampu memproses berbagai aplikasi permintaan yang diberikan oleh pengguna (Himawan, 2015). Salah satu teknologi layanan pendidikan secara online dilakukan dengan berbagai aplikasi sepeti zoom, 
google classroom, webex meeting, dll. Pemanfaatanya dapat dilakukan sesuai dengan kebutuhan masing-masing (Marbun, 2021).

\section{Pembelajaran pada Masa Pandemi Covid 19}

Salah satu kebijakan untuk menekan penyebaram Covid 19, pemerintah membuat kebijakan untuk melarang pembelajaran tatap muka, digantikan dengan pembelajaran online (Pujilestari, 2020). Dampak wabah covid-19, tidak hanya pendidikan di tingkat Sekolah tetapi juga perguruan tinggi. Seluruh jenjang pendidikan dari sekolah dasar/ibtidaiyah sampai perguruan universitas semuanya memperoleh dampak negatif karena mahasiswa belajar dari rumah karena pembelajaran tatap muka ditiadakan untuk mencegah penularan covid-19.

Padahal tidak semua mahasiswa terbiasa belajar melalui Online. Apalagi dosen masih banyak belum mahir mengajar dengan menggunakan teknologi internet atau media sosial terutama diberbagai daerah (Purwanto, 2020). Menurut (Putri, 2020) pada saat keadaan pandemi Covid-19 seperti ini, siswa dituntut untuk mengikuti pembelajaran daring yang dirasakan menyulitkan dan melelahkan oleh beberapa siswa. Dampak lain dari pandemi Covid-19 adalah siswa mengalami kebosanan karena harus belajar di rumah. Pembelajaran daring perlu dilakukan secara efektif tanpa membebani siswa dengan berbagai tugas yang harus dikumpulkan (Aji, 2020).

Terdapat kendala dalam penerapan pembelajaran berbasis online dalam perkuliahan. Persoalan ini sebenarnya bukan hanya disebabkan oleh hanya fasilitas dan sarana prasarana, namun ada faktor lain, yang juga mempengaruhinya. Selain kebiasaan positif membaca dan menemukan informasi melalui online, diskusi forum dan berbagi argumen, ide dan tulisan melalui online belum menjadi budaya di beberapa perguruan tinggi, media pembelajaran terkadang bagi sebahagian orang dianggap tidak urgen dalam pembelajaran.

\section{METODOLOGI PENELITIAN}

Penelitian ini menggunakan penelitian kualitatif. Jenis data yang digunakan adalah data primer dan data sekunder. Peneliti mendapatkan data primer secara langsung dari informan melalui pengisian Google Form. Jenis data sekunder peneliti peroleh dari artikel dan sumber data berita yang membahas tentang tema penelitian. Teknik pengambilan data dengan dokumentasi dan wawancara dengan menyebar pertanyaan melalui Google Form. Informaan dalam penelitian ini adalah mahasiswa sejumlah 128 mahasiswa, dari semester II sejumlah 50 mahasiswa, semester IV sejumlah 48 mahasiswa dan semester VI sejumlah 30 mahasiswa Program Studi Pendidikan Ekonomi Universitas PGRI Semarang.

Penelitian ini dilakukan dari bulan Maret sampai dengan bulan April 2020 ketika pada masa pandemic Covid-19. Pengecekan keabsahan jawaban informan sejumlah 128 mahasiswa, peneliti memilih 10 informan kunci yang merupakan komting atau pengurus kelas. Peneliti melakukan triangulasi data sumber dengan menelpon menggunkan apliasi Vidio Call Whatshap kepada 10 informan kunci.

Teknik analisis data dalam penelitian ini menggunakan analisis data interaktif (Miles, 2014) dengan tahapan mengkoleksi data yang berkaitan dengan tema penelitian, persepsi mahasiswa terhadap pembelajaran online pada masa pandemik Covid-19. Data dipilah sesuai dengan kebutuhan penelitian. Peneliti menyajikan data yang telah diolah dan tahapan terakhir peneliti membuat kesimpulan dari hasil penelitian tentang persepsi mahasiswa bagaimana penerapan pembelajaran online, aplikasi apa saja yang sesuai digunakan dalam pembelajaran online dan hambatan penerapan pembelajaran online pada masa pandemic Covid-19. 


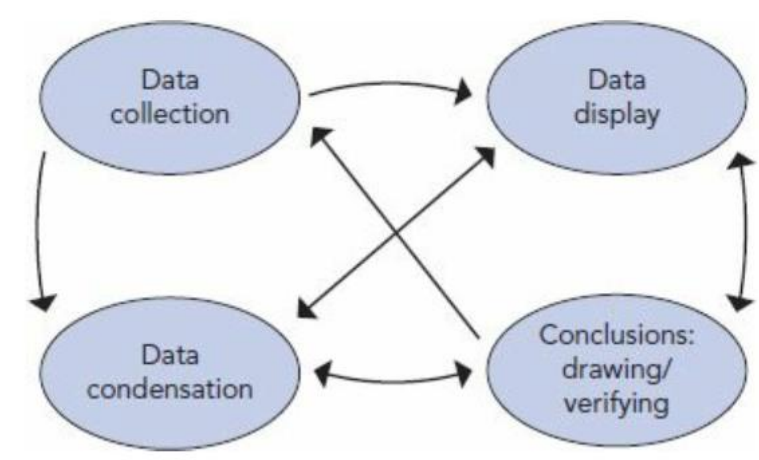

Gambar. Komponen dalam analis data (Interactif Model)

Sumber : (Miles, 2014)

\section{HASIL PENELITIAN}

\section{Penerapan Pembelajaran Online}

Dampak dari Pandemic Covid-19 salah satunya adalah meniadakan perkuliahan secara langsung. Perkuliahan dilaksanakan dengan menggunakan pembelajaran online, hal ini sesuai dengan penelitian (Praherdhiono, 2020). Pembelajaran online dianggap sebagai alternatif yang logis pada masa pandemic Covid-19. Perkuliahan dilaksanakan dirumah masing-masing dengan menggunakan media atau aplikasi tertentu. Persepsi mahasiswa terhadap pembelajaran online dalam membantu memahami materi perkuliahan pada masa pandemic Covid-19 diperoleh hasi sebanyak 60 mahasiswa atau sebesar 46,9\% menjawab membantu, sedangkan sebanyak 68 mahasiswa atau sebesar 43,1\% menjawab tidak membantu mahasiswa dalam memahami materi perkuliahan. Alasan pembelajaran online tidak dapat membantu mahasiswa dalam memahami materi perkuliahan karena penjelasan dosen kurang jelas dibandingkan dengan kuliah secara langsung diruangan.

Persepsi mahasiswa terhadap pembelajaran online dalam meningkatkan motivasi belajar, sebanyak 50 mahasiswa atau sebesar 39,1\% menjawab bahwa pembelajaran online dapat meningkatkan motivasi belajar. Motivasi belajar mahasiswa meningkat apabila dosen menyiapkan pembelajaran dengan baik, seperti dosen membuat vidio materi pembelajaran yang menarik dan mahasiswa dapat menontonya kapan saja dan dimana saja. Sebanyak 48 mahasiswa atau sebesar $37,5 \%$ menjawab pembelajaran online tidak dapat meningkatkan belajar mahawasiswa. Mereka menjelaskan akan lebih termotivasi jika kuliah secara langsung. Pembelajaran online dianggap dianggap membosankan dan menjenuhkan, apalagi jika dosen banyak memberikan tugas, dengan waktu pengumpulan yang terbatas. Sisanya sebesar $23,4 \%$ atau sebanyak 30 mahasiswa menjawab pembelajaran online dapat meningkatkan motivasi belajar atau tidak tergantung cara mengajara dosen dan materi perkuliahan yang disampaikan.

Persepsi mahasiswa terhadap efektifitas pembelajaran online pada masa pandemic Covid19, sebesar 21,6\% atau sebanyak 27 mahasiswa menjawab pembelajaran online telah efektif dilaksanakan. Sementara sisanya sebesar 78,4 atau sebanyak 98 mahasiswa menjawab pembelajaran online belum efektif dilaksanakan. Belum efektifitasnya pembelajaran online menurut mahasiswa dikarenakan hambatan sinyal internet yang kurang stabil ketika dalam proses pembelajaran. Mengingat sebagian dari domisili mahasiswa berada di daerah pedesaan yang belum maksimal fasilitas jaringan internetnya. Beberapa mahasiswa mengaku kurang berkonsentrasi ketika pembelajaran online sedang berjalan. Hal ini dikarenakan mahasiswa sedang berbaur dengan keluarga, seringkali anggota keluarga mengganggu kosentrasi mahasiswa.

\section{Aplikasi dalam Pembelajaran Online}

Berdasarkan dari hasil wawancara dengan informan, aplikasi yang sering digunakan dalam perkuliahan online adalah Google Clasroom, Zoom, Whatshap, Slack, Schoology, Google Clasroom, Zoom, Whatshap, Slack, Schoology, Youtube, Quizizz, Edmodo dan menggunakan 
aplikasi SIP (Sistem Informasi Perkuliahan) Universitas PGRI Semarang. Persepsi mahasiswa mengenai jenis aplikasi yang efektif dalam pelaksanaan pembelajaran online dapat dilihat pada gambar berikut,

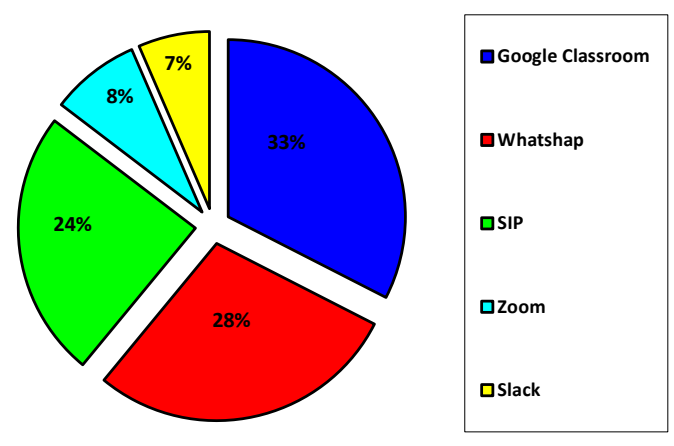

Gambar. 1 Persepsi Mahasiswa Jenis Aplikasi yang Efektif dalaPembelajaran Online Sumber. Data Olah Peneliti (2020)

Berdasarkan gambar diatas dapat dilihat persepsi mahasiswa tentang aplikasi yang dianggap efektif digunakan dalam proses pembelajaran online. Sebesar 33\% atau sebanyak 40 mahasiswa menjawab aplikasi yang sesuai untuk pembelajaran online adalah menggunakan Google Clasroom, pembelajaran menggunakan aplikasi Google Clasroom memiliki keefektifan karena kemudahan dalam penggunaanya. Menurut mahasiswa jika ingin belajar kembali materi yang telah disampaikan bisa membuka kembali aplikasi google clasroom.

Sebesar 28\% atau sebanyak 35 mahasiswa memiliki persepsi bahwa aplikasi whatshap efektif digunakan dalam pembelajaran online. Aplikasi whatshap merupakan aplikasi yang mayoritas digunakan oleh mahasiswa dalam keseharianya untuk berkomunikasi. Setiap mata kuliah dapat membuat grup whatshsap, dosen memmberikan materi berupa power point atau vidio pembelajaran yang nantinya disimak oleh mahasiswa, dengan dibuka sesi tanya jawab dan diskusi.

Sebesar 24\% atau sebanyak 30 mahasiswa memberikan persepsi bahwa SIP (Sistem Informasi Perkuliahan) Universitas PGRI Semarang, dianggap efektif digunakan dalam kegiatan pembelajaran online. SIP yang merupakan sistem pengembangan dari BPTIK kampus mampu menyediakan fasilitas pembelajaran online, teleconfrence, tugas online dan ujian online.

Sebesar 8\% atau sebanyak 10 mahasiswa memberikan persepsi bahwa aplikasi yang sesuai digunakan dalam pembelajaran online adalah aplikasi Zoom. Menurut mahasiswa aplikasi Zoom memberikan kemudahan dalam bertatap muka secara langsung meski tidak dalam satu ruangan. Mahasiswa dapat menatap dosen sehingga proses pembelajaran lebih nyata karena terdapat audio vidio. Aplikasi Zoom menurut mahasiswa memerlukan sinyal yang baik dan kuota yang lebih boros. Sebesar 7\% atau sebanyak 8 mahasiswa mejawab aplikasi Slack tepat digunakan dalam pembejaran online. Aplikasi Slack dianggap lebih mudah dan capat digunakan, akan tetapi hanya beberapa dosen saja yang baru menggunakan aplikasi Slack dalam pembalajaran online.

\section{Kelebihan dan Hambatan Pembelajaran Online pada Masa Pandemic Covid-19.}

Pelaksanaan pembelajaran online menurut persepsi mahasiswa terdapat kelebihan dan hambatan. Kelebihan pembelajaran online dimasa pandemic covid- 19 adalah mempermudah mahasiswa dan dosen tetap melaksanakan perkuliahan meskipun tidak bertemu secara langsung, hal ini sesuai dengan penelitian Anissa, dkk (2017) yang menyatakan penerapan model blended learning dapat dilaksanakan dengan membuat grup Whatshap. Mahasiswa dapat belajar secara mandiri. Sebagian mahasiswa bersyukur dengan adanya pembelajaran online dari rumah mahasiswa dapat berkumpul dengan keluarga, hal ini sesuai dengan penelitian (Kuntarto, 2017) yang menjelaskan melalui pembelajaran online mahasiswa dapat belajar dimana saja. 
Menurut mahasiswa apabila pembelajaran online tidak menggunakan aplikasi Zoom, mahasiswa dapat kuliah bersamaan dengan mengerjakan pekerjaan rumah atau membentu orang tuannya. Jika pembelajaran online menggunakan aplikasi Google Classroom, grup Whatshap, mahasiswa dapat belajar kembali kapan saja dengan melihat materi perkuliahan sebelumnya.

Selain terdapat kelebihan, pembelajaran online juga terdapat hambatan-hambatan. Menurut mahasiswa hambatan pelaksanaan pembelajaran online diantaranya adalah sinyal jaringan internet yang kurang stabil, hal ini dikarenakan sebagian mahasiswa sedang berada dirumah yang tergolong masih pedesaan dengan fasilitas jaringan internet yang belum maksimal. Sebagian mahasiswa mengeluhkan penggunaan kuota internet yang besar, terkadang ketika proses pembelajaran online sedang dilaksanakan kuota internet mahasiswa habis yang menghambat proses pembelajaran online.

Hambatan lain dalam pembelajaran online yang dirasakan oleh mahasiswa adalah tidak mudah memahami materi yang disampaikan dalam pembelajaran online. Mahasiswa lebih mudah memahami materi perkuliahan apabila dilaksanakan dengan bertemu langsung dalam satu ruangan. Ketika pembelajaran online dilaksanakan seringkali waktu perkuliahan tidak dilaksanakan sesuai dengan jadwal, sehingga kesempatan bertanya terbatas. Mahasiswa menyampaikan sebagian dosen memberikan terlalu banyak tugas.

\section{KESIMPULAN}

Simpulan dari penelitian ini adalah persepsi mahasiswa terhadap pembelajaran online sebesar 46,9\% menjawab membantu mahasiswa memahami materi perkuliahan. Sebesar 39,1\% menjawab pembelajaran online dapat meningkatkan motivasi belajar, hanya sebesar $21,6 \%$ mahasiswa menjawab pembelajaran online berjalan efektif. Aplikasi yang dianggap efektif dalam pembelajaran online adalah Google Classroom, Whatsap dan SIP. Pelaksanaan Pembelajaran online pada masa pandemic Covid-a9 memiliki kelebihan dan hambatan. Peneliti menyarankan kepada Dosen untuk memperhatikan persepsi mahasiswa terhadap pembelajaran online, terutama ketika Dosen memilih jenis aplikasi yang digunakan dalam pembelajaran online. Alangkah baiknya pemilihan aplikasi dalam pembelajaran online didiskusikan dengan mahasiswa supaya hambatan-hambatan pembelajaran online dapat diminimalisir.

\section{DAFTAR}

Abidah, A. H. (2020). The Impact of Covid-19 to Indonesian Education and Its Relation to the Philosophy of "Merdeka Belajar". . Studies in Philosophy of Science and Education, 38-49.

Aji, R. (2020). Dampak Covid-19 pada pendidikan di Indonesia: Sekolah, keterampilan, dan proses pembelajaran. SALAM: Jurnal Sosial \& Budaya, 395-402.

Alfano, V. \&. (2020). Shut it down: a cross country panel analysis on the. efficacy of lockdown measures. medRxiv.

Al-Maroof, R. A.-E. (2018). Students acceptance of Google classroom: An exploratory study using PLS-SEM approach. International Journal of Emerging Technologies in Learning (iJET), 112-123.

Alvarez, F. E. (2020). A simple planning problem for covid-19 lockdown. National Bureau of Economic Research.

Belawati, T. (2019). Pembelajaran online. Jakarta: Universitas Terbuka.

Busch, C. L.-L. (2020). Emerging Evidence of a Silver Lining But Not of Effective Lockdowns. A Ridge Walk to Avoid an Economic Catastrophe in Italy and Spain.

Darmalaksana, W. (2020). Corona Hadis. Fakultas Ushuluddin UIN Sunan Gunung Djati Bandung.

Djaja, S. (2017). Harapan dan Tantangan Guru Pembelajar Moda Daring. Jurnal Pendidikan Ekonomi: Jurnal Ilmiah Ilmu Pendidikan, Ilmu Ekonomi dan Ilmu Sosial.

Henderson, A. J. (2003). The Elearning Question and Answer Book. USA: Amacom.

Herayanti, L. F. (2017). Pengembangan Media Pembelajaran Berbasis Moodle pada Mata Kuliah Fisika Dasar. Jurnal Pendidikan Fisika dan Teknologi, 205-209. 
Hilmatussa'diah, H. (2020). Mengenal Makna Bela Negara di Masa Pandemi Virus Corona (Know the Meaning of Defending the Country in the Corona Virus Pandemic Period). Available at SSRN .

Himawan, H. (2015). Analisa dan Perancangan Sistem Pembelajaran Online Menggunakan Metode Parsing Informasi. Telematika: Jurnal Informatika dan Teknologi .

Jati, B. J. (2020). Optimalisasi Upaya Pemerintah Dalam Mengatasi Pandemi Covid 19 Sebagai Bentuk Pemenuhan Hak Warga Negara. SALAM: Jurnal Sosial dan Budaya Syar-i.

$\mathrm{Ku}, \mathrm{C}$. C. (2020). Epidemiological benchmarks of the COVID-19 outbreak control in China after Wuhan's lockdown: a modelling study with an empirical approach. Available at SSRN.

Kuntarto, E. (2017). Keefektifan Model Pembelajaran Daring dalam Perkuliahan Bahasa Indonesia di Perguruan Tinggi. Indonesian Language Education and Literature, 99-110.

Kuntarto, E. (2017). Keefektifan Model Pembelajaran Daring dalam Perkuliahan Bahasa Indonesia di Perguruan Tinggi. Indonesian Language Education and Literature, 99-110.

Lau, H. K. (2020). The positive impact of lockdown in Wuhan on containing the COVID-19 outbreak in China. Journal of Travel Medicine.

Marbun, P. (2021). Disain pembelajaran online pada era dan pasca covid-19. (Computer Science Research and Its Development Journal), 129-142.

Miles, M. B. (2014). Qualitative data analysis: A methods sourcebook. Los Angeles: Sage.

Mitjà, O. A. (2020). Experts' request to the Spanish Government: move Spain towards complete lockdown. Lancet (London, England), .

Mungkasa, O. (2020). Bekerja Jarak Jauh (Telecommuting): Konsep, Penerapan dan Pembelajaran. Bappenas Working Papers, 1-32.

Piguillem, F. \&. (2020). The optimal covid-19 quarantine and testing policies (No. 2004). Einaudi Institute for Economics and Finance (EIEF).

Praherdhiono, H. A. (2020). Implementasi Pembelajaran di Era dan Pasca Pandemi COVID-19. Seribu Bintang.

Praherdhiono, H. A. (2020). Implementasi Pembelajaran di Era dan Pasca Pandemi COVID-19. Seribu Bintang.

Prajana, A. (2017). Pemanfaatan Aplikasi Whatsapp dalam Media Pembelajaran di UIN ArRaniry Banda Aceh. Cyberspace. Jurnal Pendidikan Teknologi Informasi, 122-133.

Pujilestari, Y. (2020). Dampak Positif Pembelajaran Online Dalam Sistem Pendidikan Indonesia Pasca Pandemi Covid-19. 'ADALAH.

Purwanto, A. P. (2020). Studi Eksploratif Dampak Pandemi COVID-19 Terhadap Proses Pembelajaran Online di Sekolah Dasar. EduPsyCouns: Journal of Education, Psychology and Counseling, 1-12.

Purwanto, A. P. (2020). Studi Eksploratif Dampak Pandemi COVID-19 Terhadap Proses Pembelajaran Online di Sekolah Dasar. EduPsyCouns. Journal of Education, Psychology and Counseling, 1-12.

Putri, C. D. (2020). Problem Based Learning Terintegrasi STEM Di Era Pandemi Covid-19 Untuk Meningkatkan Keterampilan Berpikir Kritis Siswa. JIPI (Jurnal IPA \& Pembelajaran IPA), 193-204.

Sanjaya, R. (2020). 21 Refleksi Pembelajaran Daring di Masa Darurat. SCU, Knowledge Media. Telaumbanua, D. (2020). Urgensi Pembentukan Aturan Terkait Pencegahan Covid-19 di Indonesia. QALAMUNA: Jurnal Pendidikan, Sosial, dan Agama, 59-70. 